УДК 544.4:674.03:678

\title{
ИЗУЧЕНИЕ ВЛИЯНИЯ ВИДА НАПОЛНИТЕЛЯ НА КИНЕТИКУ ОТВЕРЖДЕНИЯ КОМПОЗИЦИОННЫХ МАТЕРИАЛОВ НА ОСНОВЕ ФЕНОЛКАРДАНОЛФОРМАЛЬДЕГИДНЫХ НОВОЛАЧНЫХ СМОЛ
}

(C) О.Ф. Шиилов ${ }^{1 *}$, С.А. Дождиков ${ }^{1}$ В.В. Глухих ${ }^{2}$

\author{
'ОАО «Уралхимпласт», Северное шоссе, 21, Нижний Тагил, Свердловская \\ область, 622012 (Россия), e-mail: shishlov@ucp.ru \\ ${ }^{2}$ Уральский государственный лесотехнический университет, Сибирский \\ тракт, 37, Екатеринбург, 620100 (Россия), e-mail: vvg@usfeu.ru.
}

В данном исследовании изучалось влияние вида наполнителя растительного происхождения на кинетику отверждения композиционных материалов на основе фенолкарданолформальдегидных новолачных смол. В качестве растительного сырья для получения наполнителей были выбраны традиционно используемые в деревоперерабатывающей промышленности лиственные и хвойные породы, а также твердолиственные породы, тропические лиственные породы и травянистые растения. Установлено влияние наполнителя растительного происхождения на значение эффективной энергии активации $E_{a}$ в зависимости от степени отверждения $(\alpha)$ и на порядок реакции отверждения.

Ключевые слова: карданол, кинетика, энергия активации, порядок реакции, композиционные материалы, растительное сырье.

\section{Введение}

Для получения композиционных материалов на основе древесной муки и порошкообразных новолачных фенолформальдегидных смол перспективным представляется использование олигомеров, полученных с частичной заменой фенола на возобновляемый продукт растительного происхождения - карданол, выделяемый из жидкости скорлупы орехов кешью $[1,2]$.

Карданол представляет собой смесь алкилфенолов, состоящую преимущественно из 3-пентадецилфенола, 3-(8(Z)-пентадеценил)фенола, 3-(8(Z),11(Z)-пентадекадиенил)фенола и 3-(8(Z),11(Z),14-пентадекатриенил) фенола [1].

Полимеры, содержащие в составе карданол, обладают повышенной водостойкостью, устойчивостью к действию кислот и щелочей, имеют высокое электрическое сопротивление, устойчивы к истиранию, износу, повреждению термитами [3]. Наличие в метаположении $\mathrm{C}_{15}$ углеводородного заместителя придает полимерам эффект внутренней пластификации и растворимость в углеводородных растворителях, маслах [2].

Целью данного исследования является изучение влияния вида наполнителя растительного происхождения на кинетику отверждения композиционных материалов на основе фенолкарданолформальдегидных новолачных смол.

Шишлов Олег Федорович - директор по науке и развитию, кандидат технических наук, тел.: (3435) 34-65-92, e-mail: o.shishlov@ucp.ru Дождиков Сергей Александрович - ведущий инженер центральной лаборатории, тел.: (3435) 34-67-93, e-mail: s.dozhdikov@ucp.ru

Глухих Виктор Владимирович - профессор кафедры технологии переработки пластических масс, доктор технических наук, тел.: (3432) 62-97-46, e-mail:vvg@usfeu.ru

\section{Экспериментальная часть}

Для изучения кинетики отверждения композиционных материалов (КМ) в лабораторных условиях использовали фенолкарданолформальдегидную новолачную смолу ФКФС-20 [4], гексаметилентетрамин по ГОСТ 1381-73 и измельченные частицы различных видов растительного сырья (табл. 1).

\footnotetext{
* Автор, с которым следует вести переписку.
} 
Таблица 1. Растительное сырье

\begin{tabular}{|c|c|}
\hline Наименование сырья & Место произрастания \\
\hline \multicolumn{2}{|l|}{ 1. Древесное сырье: } \\
\hline \multicolumn{2}{|l|}{ 1.1. Хвойные породы: } \\
\hline Сосна обыкновенная (Pinus sylvestris L.) & Урал \\
\hline Ель обыкновенная (Picea abies (L.) H.Karst.) & Урал \\
\hline Лиственница сибирская (Larix sibirica Ledeb.) & Урал \\
\hline Древмука М 180 по ГОСТ 16361-87 (массовая доля древесины лиственных пород н.б. 5\%) & Россия, Марий Эл \\
\hline \multicolumn{2}{|l|}{ 1.2. Лиственные породы: } \\
\hline Береза повислая (Betula pendula Roth) & Урал \\
\hline Осина обыкновенная (Populus tremula L.) & Урал \\
\hline Бук европейский (Fagus sylvatica L.) & Европа \\
\hline Дуб черешчатый (Quercus robur L.) & Средняя полоса России \\
\hline Клен остролистый (Acer platanoides L.) & Средняя полоса России \\
\hline Черное дерево (мунский эбен) (Diospyros mun A.Chev.) & Вьетнам \\
\hline Квебрахо (Schinopsis balansae Engl.) & Бразилия \\
\hline \multicolumn{2}{|l|}{ 2. Недревесное сырье: } \\
\hline Бамбук (Bambusoideae Luerss.) & Индия, Тамил Наду \\
\hline $\begin{array}{l}\text { Тростник обыкновенный } \\
\text { (Phragmites communis Trin.) «камыш» }\end{array}$ & Казахстан \\
\hline
\end{tabular}

В качестве растительного сырья для получения наполнителей были выбраны традиционно используемые в отечественной деревоперерабатывающей промышленности лиственные (береза, осина) и хвойные (ель, сосна, лиственница) породы, твердолиственные породы (клен, дуб, бук), а также тропические лиственные породы (квебрахо, черное дерево) и травянистые растения (бамбук, камыш).

Измельчение растительного сырья проводили на высокоскоростной роторной мельнице «Pulverisette 14» производства компании FRITSCH с использованием кольцевого сита с трапецеидальными отверстиями диаметром 0,08 мм.

Для изучения кинетики отверждения композиционных материалов использовали дифференциальный сканирующий калориметр Mettler Toledo DSC 823e/700. Измерения тепловых потоков на анализаторе DSC (ДСК измерения) проводились в закрытых алюминиевых 40 мкл тиглях, способных выдержать давление паров до 0,2 МПа. Динамические ДСК измерения проводились при скоростях нагрева 5, 10 и $20{ }^{\circ} \mathrm{C} / \mathrm{мин}$ в диапазоне температур от 25 до $350{ }^{\circ} \mathrm{C}$. Масса навесок образцов была в пределах 4-8 мг.

Кинетические расчеты проводили по известным алгоритмам [5, 6].

\section{Результаты и их обсуждение}

Методом DSC была изучена кинетика реакции отверждения фенолкарданолформальдегидного олигомера ФКФС-20 (содержание карданола в исходной смеси фенол : карданол 20\%) с гексаметилентетрамином (ГМТА) в присутствии наполнителя - частиц, полученных измельчением растительного сырья. Было выбрано следующее массовое соотношение компонентов смеси:

ФКФС-20 : наполнитель : ГМТА = $100: 93: 12$.

Смесь исходных компонентов помещалась в закрытый алюминиевый тигель и нагревалась с постоянной скоростью 5,10 и $20{ }^{\circ} \mathrm{C} /$ мин до достижения температуры тигля $350{ }^{\circ} \mathrm{C}$. Примеры полученных кривых ДСК приведены на рисунке 1.

При изучении кинетики реакции отверждения композиционных материалов в условиях ДСК измерений максимальная «калориметрическая» степень превращения $(\alpha)$ принималась за $100 \%$.

Для оценки кинетических параметров реакции применялись различные кинетические методы модельной и безмодельной кинетики.

Первоначально были выполнены расчеты кинетических параметров реакции отверждения смесей на основе ФКФС-20 и наполнителя методами безмодельной кинетики: Озавы - Флинна - Уолла, Фридмана, Вязовкина, стандарта США ASTM Е698 [5-9]. Результаты данных расчетов показали зависимость эффективной энергии активации $\left(E_{a}\right)$ реакции отверждения от степени превращения $\alpha$.

Значения энергии активации $E_{a}$ реакции отверждения смесей с различными наполнителями, определенные различными методами, сопоставимы (рис. 2). 


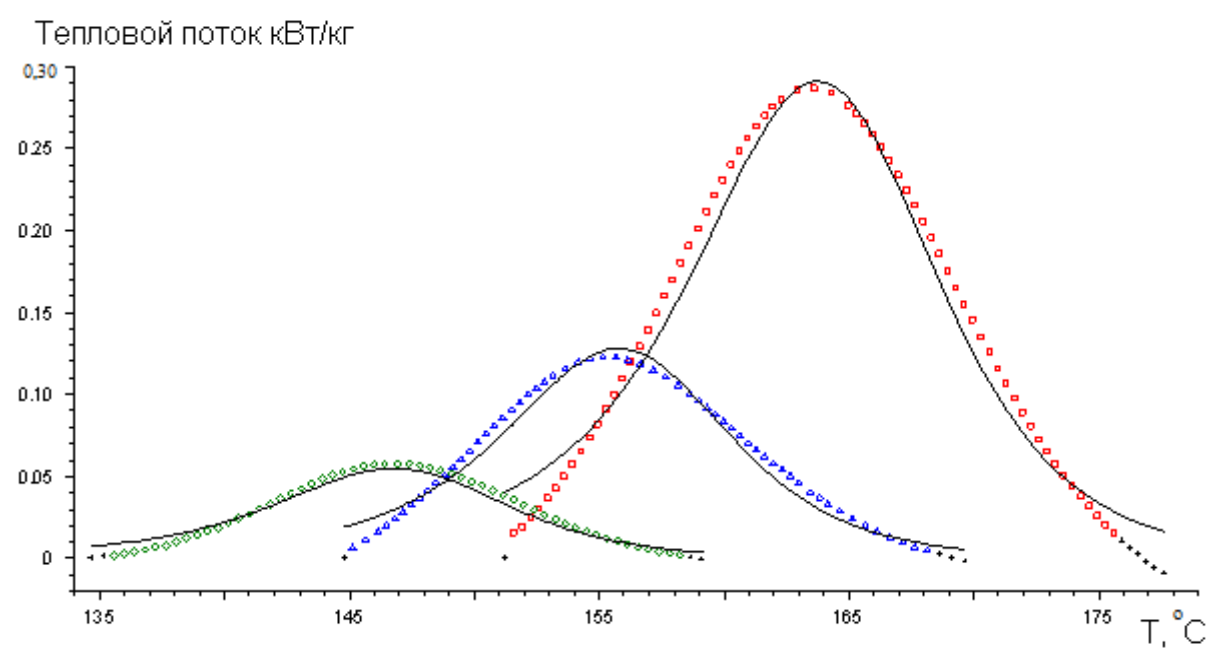

Рис. 1. Экспериментальные ( $(\Delta, \Delta)$ и расчетные $(-)$ кривые ДСК реакции отверждения КМ на основе ФКФС-20 и древесного наполнителя (сосна) для одностадийной кинетической модели n-го порядка с автокатализом при скорости нагрева 5,10 и $20{ }^{\circ} \mathrm{C} /$ мин

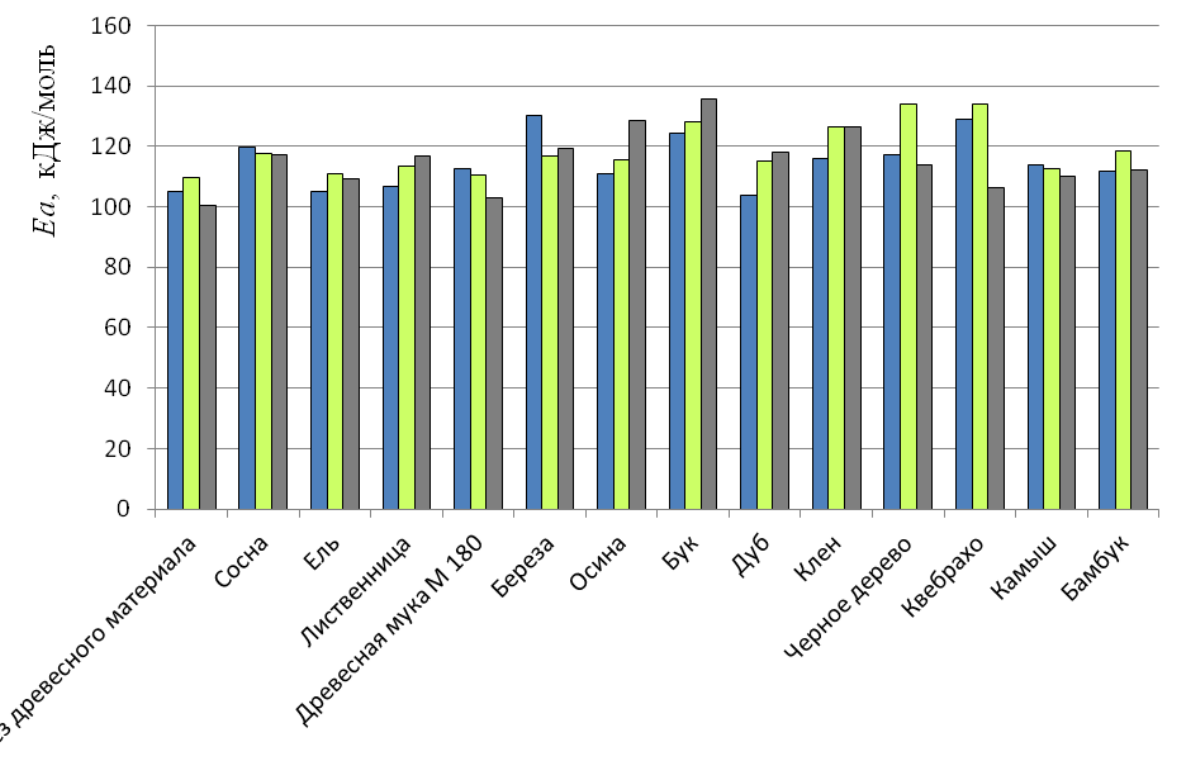

Рис. 2. Энергии активации отверждения КМ с различными наполнителями: $\square$ метод Фридмана, $a=50 \%, \square$ метод АSTM Е698, $\square$ метод Вязовкина, $a=50 \%$

Анализ результатов расчетов по методу Фридмана позволил предположить наличие эффекта автокатализа в начале процесса при малых величинах $\alpha$ (рис. 3), так как линии, соединяющие экспериментальные точки (при 1000/Т > 2,30) имеют больший угол наклона к оси абсцисс, чем линии изоконверсии. При этом хорошее описание (по величине коэффициента корреляции $r$ ) кривых ДСК (рис. 1) наблюдается при использовании следующей кинетической модели реакций $n$-го порядка с автокатализом:

$$
\frac{d \alpha}{d \tau}=\mathrm{Ae}^{-\frac{\mathrm{E}_{\mathrm{a}}}{\mathrm{RT}}}\left(1+K_{c a t} \alpha\right)(1-\alpha)^{n},
$$

где $\alpha$ - степень превращения, $\tau$ - время протекания реакции, $A$ - предэкспоненциальный множитель; $E_{a}-$ эффективная энергия активации, $R$ - универсальная газовая постоянная, $T$ - температура, $K_{c a t}-$ константа автокатализа реакции, $n$ - общий порядок реакции.

В таблице 2 представлены результаты кинетических расчетов по данной кинетической модели для реакции отверждения композиционных материалов. 


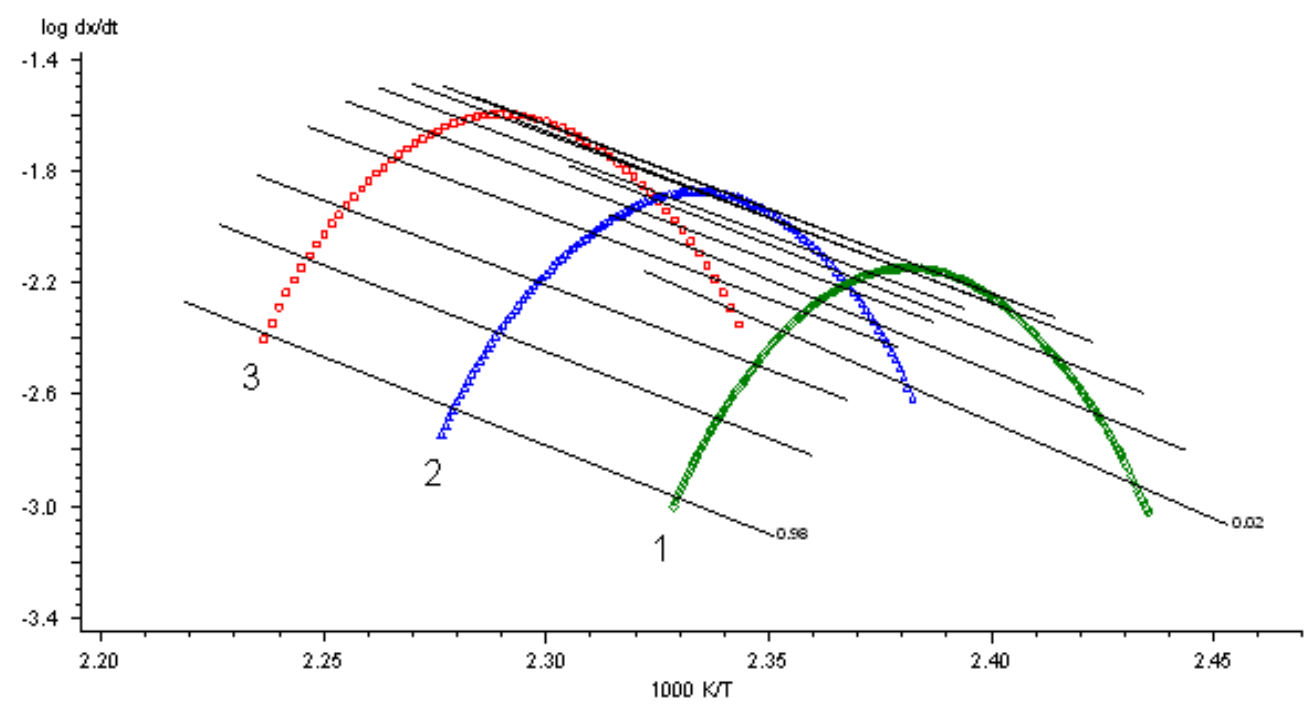

Рис. 3. График Фридмана для реакции отверждения смеси на основе ФКФС-20 и соснового древесного наполнителя при скорости нагрева: $1-5{ }^{\circ} \mathrm{C} /$ мин, $2-10{ }^{\circ} \mathrm{C} /$ мин и $3-20{ }^{\circ} \mathrm{C} /$ мин

Таблица 2. Кинетические параметры реакции отверждения (кинетическая модель реакции $n$-го порядка с автокатализом) композиционных материалов

\begin{tabular}{l|c|c|c|c}
\hline \multicolumn{1}{c|}{ Вид наполнителя } & $E_{a}$, кДж/моль & $\log A$ & $n$ & $r$ \\
\hline Без наполнителя & 104,92 & 10,05 & 1,79 & 0,9895 \\
Сосна & 119,77 & 12,29 & 1,32 & 0,9940 \\
Ель & 104,89 & 10,35 & 1,22 & 0,9902 \\
Лиственница & 106,78 & 10,61 & 1,28 & 0,9889 \\
Древесная мука М 180 & 112,60 & 11,33 & 1,18 & 0,9920 \\
Береза & 130,34 & 13,50 & 1,43 & 0,9908 \\
Осина & 110,95 & 11,01 & 1,26 & 0,9915 \\
Бук & 124,41 & 12,91 & 1,26 & 0,9899 \\
Дуб & 103,96 & 10,25 & 1,21 & 0,9866 \\
Клен & 115,98 & 11,73 & 1,30 & 0,9944 \\
Черное дерево & 117,32 & 11,94 & 1,62 & 0,9749 \\
Квебрахо & 128,89 & 13,51 & 1,62 & 0,9860 \\
Камыш & 113,84 & 11,50 & 1,25 & 0,9892 \\
Бамбук & 111,93 & 11,15 & 1,30 & 0,9923 \\
\hline
\end{tabular}

Порядок реакции, рассчитанный по кинетической модели (табл. 2), сопоставим для большинства изученных древесных пород $(n=1,18-1,43)$ и отличается в случае использования тропических лиственных пород квебрахо и черное дерево $(n=1,62)$ и отверждения материала без древесного наполнителя $(n=1,79)$ (рис. 4). Изменение значения порядка реакции может предполагать изменение механизма реакции - в случае тропических пород за счет повышенного содержания в составе древесины таннинов - реакционноспособных соединений фенольного типа [10].

Зависимость эффективной энергии активации от степени отверждения ( $\alpha$ ) КМ от вида наполнителя (рис. 5) была изучена с помощью метода Вязовкина [8, 9]. В отличие от метода по стандарту ASTM E698, который позволяет определить энергию активации только для максимальной скорости реакции, метод Вязовкина позволяет получить зависимость энергии активации от степени отверждения $(\alpha)$, и является удобным инструментом для обсуждения механизма реакции.

Энергия активации отверждения КМ зависит от химического состава, плотности и структуры древесного материала. Наличие в составе материала соединений, способных участвовать в реакции отверждения фенолкарданолформальдегидных олигомеров с ГМТА, позволяет получать более низкие значения энергии активации реакции отверждения КМ. Использование древесных пород, характеризующихся высокой плотностью и низкой пористостью, замедляет диффузию расплава смолы в структуру древесного материала и характеризуется высокими значениями энергии активации при низкой степени превращения материала, и наоборот, низкими значениями энергии активации при высокой степени превращения материала. 


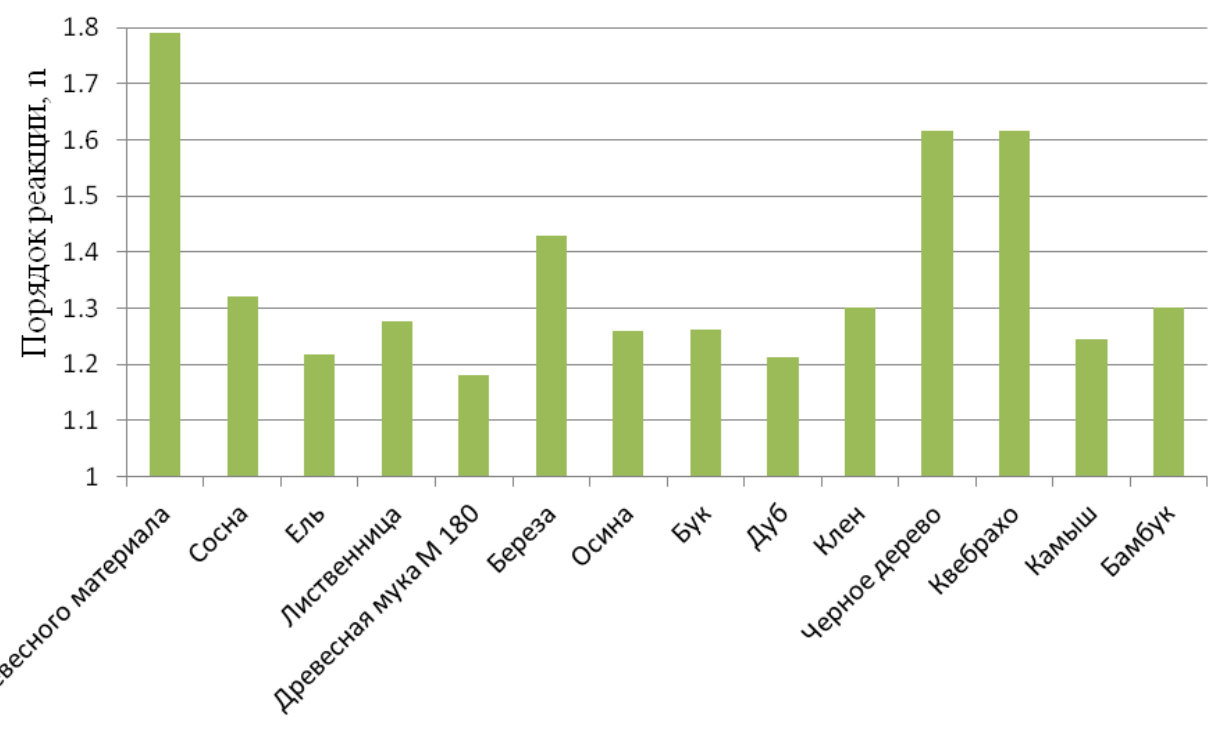

Рис. 4. Зависимость порядка реакции отверждения КМ от вида наполнителя

Самую высокую реакционную способность и соответственно самые низкие значения энергии активации при различной степени превращения имеет древесина квебрахо, в составе которой присутствуют высокореакционноспособные соединения таннины в количестве до 40\% [11].

Древесина другой тропической породы - черного дерева характеризуется наличием в составе, кроме таннинов, реакционноспособных соединений нафталинового ряда [12, 13], содержащих гидроксильные, метоксильные и альдегидные группы (6-гидрокси-4,5диметокси-2-нафтальдегид). Несмотря на высокую плотность древесины квебрахо и черного дерева, наличие высокореакционноспособных соединений приводит к протеканию реакции отверждения с низкими значениями энергии активации.

Лигнин, в отличие от целлюлозы, является соединением, способным вступать в реакцию с фенолкарданолформальдегидными олигомерами в присутствии отвердителя ГМТА (рис. 6).

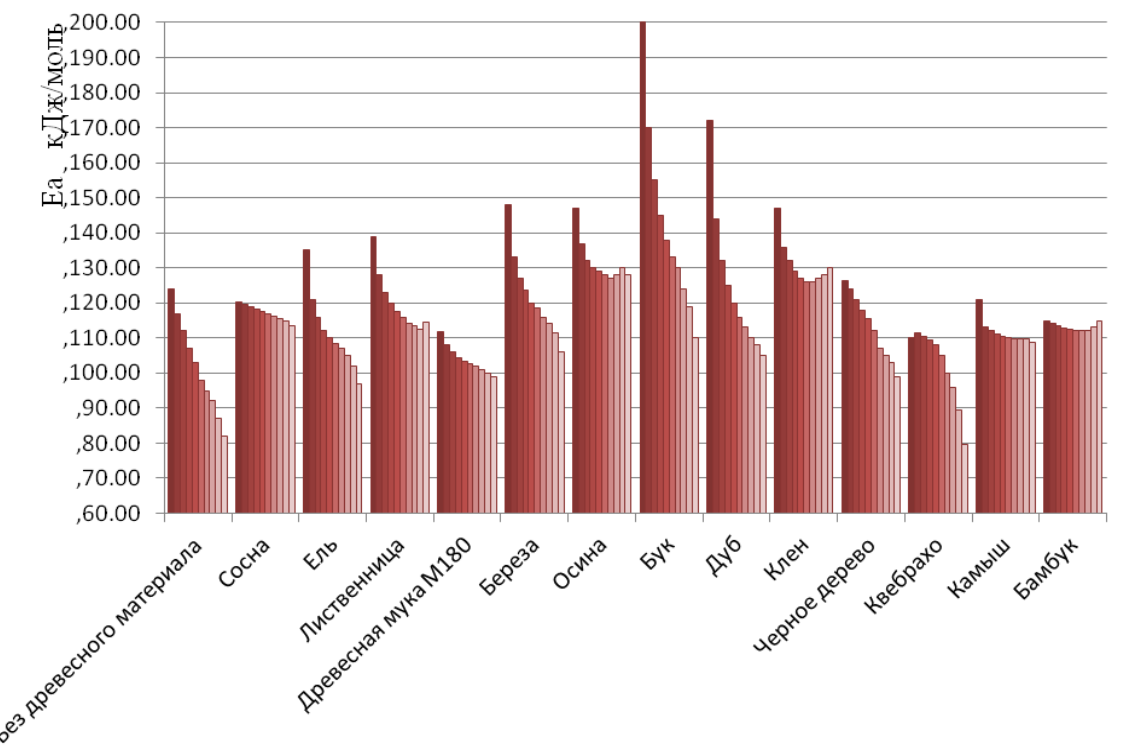

Рис. 5. Зависимость энергии активации отверждения КМ от вида наполнителя при различной степени отверждения материала $(\alpha): \square-5 \%, \square-15 \%, \square-25 \%, \square-35 \%, \square-45 \%, \square-55 \%, \square-65 \%$, $-75 \%, \square-85 \%, \square-85 \%$ 


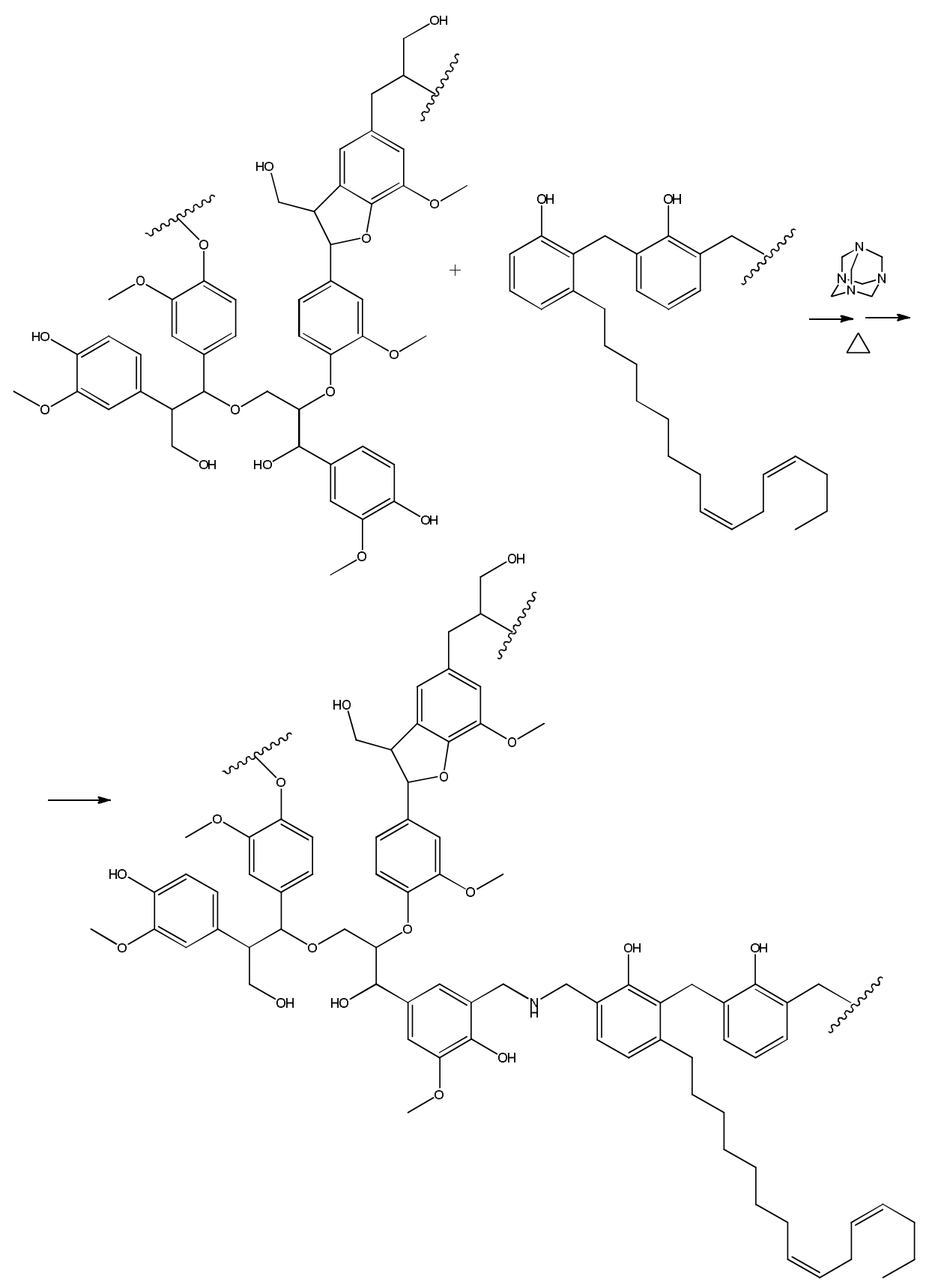

Рис. 6. Реакция взаимодействия фенолкарданолформальдегидной новолачной смолы с лигнином в присутствии ГМТА

Таким образом, КМ, содержащие материалы с повышенным содержанием лигнина, будут иметь пониженное значение энергии активации при реакции отверждения. Содержание лигнина в древесине хвойных пород составляет 26-29\% и превышает его содержание в древесине лиственных пород 19-26\% [10, 11]. Энергия активации реакции отверждения ДКМ, содержащего древесную породу - ель, при низких степенях превращения ниже, чем в случае использования лиственных пород, но выше, чем в случае использования сосны. Для древесины сосны характерно повышенное содержание экстрагируемых эфиром веществ (4,1-4,6\%), которые на 30-40\% состоят из смоляных кислот (абиетиновая, левопимаровая) [10]. Для сравнения, содержание экстрагируемых эфиром веществ для различных древесных пород: ель 0,9-1,1\%, лиственница 1,8\%, дуб 0,5\% [10]. Смоляные кислоты хорошо совмещаются с фенолформальдегидными смолами, ускоряют реакцию их отверждения с ГМТА и сами вступают с ними в химическую реакцию [14]. Смоляные кислоты могут ускорять диффузию расплава фенолкарданолформальдегидного олигомера в структуру древесного материала, поэтому энергия активации при использовании сосны более низкая при начальных степенях превращения ДКМ. 
При высокой степени превращения энергия активации в случае использования материала, содержащего ель, резко снижается за счет взаимодействия лигнина с фенолкарданолформальдегидным олигомером, что было ограничено при начальных степенях превращения КМ за счет фактора пониженной диффузии расплава в структуру древесного материала.

Древесина лиственницы характеризуется содержанием лигнина до 26\%, наличием в составе водорастворимого полисахарида арабиногалактана (10-15\%), флавоноидов (до 3,5\%), которые представлены однотипными по химическому строению флавоновыми соединениями с преобладающим (> 80\%) содержанием дигидрокверцетина, в т.ч. и полимерами дигидрокверцетина $[15,16]$. Более высокие значения энергии активации при начальных значениях степени превращения можно объяснить влиянием фактора замедленной диффузии расплава фенолкарданолформальдегидного олигомера в плотную структуру древесины лиственницы, а снижение энергии активации при высоких значениях степени превращения - за счет взаимодействия олигомера и ГМТА с лигнином и флавоновыми соединениями.

Березовая древесина отличается от других пород деревьев наличием большого количества гемицеллюлоз (массовая доля до 30\%) и высокой плотностью древесины, что обусловливает высокие значения энергии активации при начальных значениях степени превращения и понижение энергии активации при высоких значениях степени превращения за счет взаимодействия фенолкарданолформальдегидного олигомера с ГМТА и лигнином (содержание лигнина 20-21\%) [10, 17].

Наличие небольшого количества реакционноспособных соединений в структуре древесины осины объясняет незначительное снижение значения энергии активации при увеличении степени отверждения КМ. Содержание лигнина в древесине осины составляет примерно 22\% [10], но состав лигнина осины отличается от состава лигнина березы: карбонильных групп в лигнине березы больше в 1,3 раза, а количество алифатических спиртовых групп в лигнине осины больше в 11,7 раз [18].

Древесина бука и дуба имеет высокую плотность, соответственно для реакции отверждения ДКМ характерна высокая энергия активации при низкой степени превращения вследствие низкой диффузии расплава в древесный материал. При более высоких значениях степени превращения энергия активации резко снижается за счет взаимодействия фенолкарданолформальдегидного олигомера с реакционноспособными соединениями: лигнином (содержание в древесине дуба 22-27\% [10], бука - 20-23\% [11]), эллаговой кислотой, содержащейся в дубовой древесине [19], глюкованилином, содержащимся в буковой древесине [20].

Древесина клена также имеет высокую плотность и характеризуется невысоким содержанием реакционноспособных соединений, поэтому энергия активации в данном случае проходит через минимум при $\alpha=60 \%$ (рис. 5 ).

Травянистые растения бамбук и камыш имеют низкую плотность, что обусловливает пониженное значение энергии активации при низких значениях степени превращения ДКМ за счет высокой диффузии расплава в пористую структуру материала. Содержание лигнина в камыше 18-20\% [21, 22] и бамбуке 22\% [22] не оказывает значительного влияния на снижение энергии активации при повышенных значениях степени превращения ДКМ. Данные растения характеризуются повышенным содержанием кремния (в испытанных образцах бамбука и камыша содержание $\mathrm{SiO}_{2}$ составляет $0,99 \%$ и 1,35\% соответственно) и калия, который содержится в растениях в виде силиката калия [23]. Вопрос влияния силиката калия на реакционную способность фенолкарданолформальдегидного олигомера в реакции с ГМТА требует дальнейшего изучения.

Промышленно доступная марка древесной муки М180, с содержанием массовой доли лиственных пород не более $5 \%$ при изучении зависимости значения энергии активации от степени превращения ведет себя аналогично смеси древесных материалов ели и сосны, с преобладанием в составе последней.

Реакция отверждения фенолкарданолформальдегидного олигомера с ГМТА без древесного материала протекает с равномерным снижением значения энергии активации в зависимости от увеличения степени превращения.

\section{Выводы}

1. Наполнитель растительного происхождения оказывает влияние на кинетику отверждения композиционных материалов на основе фенолкарданолформальдегидных новолачных смол за счет взаимодействия реакционно способных соединений, содержащихся в природном материале, с карданолсодержащими олигомерами в условиях образования полимера с ГМТА.

2. Порядок реакции, рассчитанный с помощью метода безмодельной кинетики по С. Вязовкину, сопоставим для большинства изученных древесных пород $(n=1,18-1,43)$ и отличается в случае использования тропических лиственных пород квебрахо и черное дерево $(n=1,62)$. Изменение значения порядка ре- 
акции предполагает изменение механизма реакции - в случае тропических пород за счет повышенного содержания в составе древесины таннинов.

3. Использование древесных пород, характеризующихся высокой плотностью и низкой пористостью, замедляет диффузию расплава смолы в структуру древесного материала и характеризуется высокими значениями энергии активации при низкой степени превращения материала и наоборот, низкими значениями энергии активации при высокой степени превращения материала.

4. Метод безмодельной кинетики по Вязовкину представляет собой удобный инструмент для изучения влияния состава напонителя на кинетические параметры реакции поликонденсации композиционного материала - эффективную энергию активации $E_{a}$ в зависимости от степени отверждения $(\alpha)$ и порядок реакции отверждения $(n)$.

\section{Список литературы}

1. Talbiersky J., Polaczek J., Ramamoorty R., Shishlov O. Phenols from Cashew Nut Shell Oil as a Feedstock for Making Resins and Chemicals // OIL GAS Europeen Magazine. 2009. №1. Pp. 33-39.

2. Шишлов О.Ф., Глухих В.В. Синтез, свойства и применение продуктов поликонденсации карданола с формальдегидом (обзор) // Химия растительного сырья. 2011. №1. С. 5-16.

3. Venmalar D., Nagaveni H.C. Evaluation of copperised cashew nut shell liquid and neem oil as wood preservatives // 36th Ann. Meeting of the Intern. Research Group on Wood Protection, 24-28 April 2005, Bangalore, India. IRG/WP 05-30368 $20 \mathrm{p}$.

4. Шишлов О.Ф., Дождиков С.А., Глухих В.В., Стоянов О.В. Изучение влияния содержания карданола на свойства фенолкарданолформальдегидных новолачных смол // Клеи. Герметики.Технологии. 2013. №5. С. 15-18.

5. He G., Riedl B., Aït-Kadi A. Model-free kinetics: Curing behavior of phenol formaldehyde resins by differential scanning calorimetry // J. Appl. Polym. Sci. 2003. Vol. 87. Issue 3. Pp. 433-440. doi: 10.1002/app.11378

6. Wang J., Laborie M.-P.G., Wolcott M.P. Comparison of model-fitting kinetics for predicting the cure behavior of commercial phenol-formaldehyde resins // J. Appl. Polym. Sci. 2007. Vol. 105. Issue 3. Pp. 1289-1296. doi: 10.1002/app. 24855

7. Friedman H. L. New methods for evaluating kinetic parameters from thermal analysis data // J. Polym. Sci. B Polym. Lett. 1969. Vol. 7. Issue 1. Pp. 41-46. doi: 10.1002/pol.1969.110070109

8. Vyazovkin S., Burnham A.K., Criado J.M., Pérez-Maqueda L.A., Popescu C., Sbirrazzuoli N. ICTAC Kinetics Committee recommendations for performing kinetic computations on thermal analysis data // Thermochimica Acta. 2011. Vol. 520. Issues 1-2. Pp. 1-19. doi: 10.1016/j.tca.2011.03.034.

9. Vyazovkin S. Evaluation of activation energy of thermally stimulated solid-state reactions under arbitrary variation of temperature // J. Comput. Chem. 1997. Vol. 18. Issue 3. Pp. 393-402. doi: 10.1002/(SICI)1096987X(199702)18:3<393::AID-JCC9>3.0.CO;2-P

10. Никитин В.М., Оболенская А.В., Щеголев В.П. Химия древесины и целлюлозы. М., 1978. 368 с.

11. Древесиноведение. Химический состав древесины. [Электронный pecypc]. URL: http://delostroika.ru/org/dreved/him/3990-himicheskiy-sostav-drevesiny.html

12. Koichiro Kitao. Chemical Constituents of Tropical Woods, (in Japanese) p. 6.

13. Brown A.G., Thomson R.H. 792. Ebenaceae extractives. Part II. Naphthaldehydes from Diospyros ebenum koen // J. Chem. Soc. 1965. Pp. 4292-4295. doi: 10.1039/JR9650004292

14. Кноп А., Шейб В. Фенольные смолы и материалы на их основе. М., 1983. 280 с.

15. Бабкин В.А., Остроухова Л.А., Малков Ю.А., Иванова С.З., Онучина Н.А., Бабкин Д.В. Биологически активные экстрактивные вещества из древесины лиственницы // Химия в интересах устойчивого развития. 2001. №3. C. 363-367.

16. Иванова С.З., Федорова Т.Е., Остроухова Л.А., Федоров С.В., Онучина Н.А., Бабкин В.А. Полимер дигидрокверцетина из древесины лиственницы // Химия растительного сырья. 2001. №4. С. 21-24.

17. Кузнецов Б.Н., Кузнецова С.А., Данилов В.Г., Тарабанько В.Е. Получение химических продуктов из древесины березы методами каталитического окисления и кислотного катализа // Химия в интересах устойчивого развития. 2005. №4. С. 531-539.

18. Судакова И.Г., Кузнецов Б.Н., Гарынцева Н.В., Королькова И.В. Состав и связующие свойства лигнинов, полученных окислительной делигнификацией древесины пихты, осины и березы в среде уксусной кислоты // Химия растительного сырья. 2010. №3. С. 55-60.

19. Никитин Н. И. Химия древесины и целлюлозы. М.; Л., 1982, 711 с.

20. Karrer W. Konstitution und Vorkommen der organischen Pflanzenstoffe. Basel, Stuttgart, 1958. 1207 p.

21. Зотов П.Д. Производство строительных плит из камыша. УзФАН. Ташкент, 1941. С. 6-7.

22. Wakisaka H. Development of functional materials with carbon waste product of natural resources - Yoshi - development of activated carbon from bamboo. 2007. Pp. 23-31. (in Japanese)

23. Uchimura Etsuzo. Bamboo charcoal \& vinegar. 1999. 187 p. (in Japanese) 
Shishlov O.F. ${ }^{*}$, Dozhdikov S.A. ${ }^{l}$, Gluhih V.V. ${ }^{2}$ THE INFLUENCE OF EXTENDER TYPE ON CURE KINETICS IN COMPOSITE MATERIALS BASED ON PHENOL-CARDANOL-FORMALDEHYDE NOVOLAC RESINS

${ }^{1}$ JSC «Uralchimplast», Northern Highway, 21, Nizhny Tagil, Sverdlovsk region, 622012 (Russia),

e-mail: shishlov@ucp.ru

${ }^{2}$ Ural State Forestry University, Russia, Siberian highway, 37, Ekaterinburg, 620100 (Russia), e-mail: vvg@usfeu.ru.

The influence of plant extender type on kinetics of curing in composite materials based on phenol-cardanolformaldehyde novolac resins was studied. Traditional for wood industry foliage, coniferous, hard-wooded broadleaved, tropical foliage and gramineous plants were taken as a source of fillers. The influence of plant filler on effective activation energy Ea in dependence from extent of curing and reaction order of curing reaction $(\alpha)$ were found.

Keywords: cardanol, kinetics, activation energy, reaction order, composite materials, plant raw materials.

\section{References}

1. Talbiersky J., Polaczek J., Ramamoorty R., Shishlov O. OIL GAS Europeen Magazine, 2009, no. 1, pp. 33-39.

2. Shishlov O.F., Gluhih V.V. Himija rastitel'nogo syr'ja, 2011, no. 1, pp. 5-16. (in Russ.)

3. Venmalar D., Nagaveni H.C. 36th Ann. Meeting of the Intern. Research Group on Wood Protection, 24-28 April 2005, Bangalore, India, IRG/WP 05-30368, 20 p.

4. Shishlov O.F., Dozhdikov S.A., Gluhih V.V., Stojanov O.V. Klei. Germetiki. Tehnologii, 2013, no. 5, pp. 15-18. (in Russ.)

5. He G., Riedl B., Aitt-Kadi A. J. Appl. Polym. Sci., 2003, vol. 87, issue 3, pp. 433-440, doi: 10.1002/app.11378.

6. Wang J., Laborie M.-P.G., Wolcott M.P. J. Appl. Polym. Sci., 2007, vol. 105, issue 3, pp. 1289-1296, doi: 10.1002/app.24855.

7. Friedman H. L. J. Polym. Sci. B Polym. Lett., 1969, vol. 7, issue 1, pp. 41-46, doi: 10.1002/pol.1969.110070109.

8. Vyazovkin S., Burnham A.K., Criado J.M., Pérez-Maqueda L.A., Popescu C., Sbirrazzuoli N. Thermochimica Acta, 2011, vol. 520, issues 1-2, pp. 1-19, doi: 10.1016/j.tca.2011.03.034.

9. Vyazovkin S. J. Comput. Chem., 1997, vol. 18, issue 3, pp. 393-402, doi: 10.1002/(SICI)1096987X(199702)18:3<393::AID-JCC9>3.0.CO;2-P.

10. Nikitin V.M., Obolenskaja A.V., Shhegolev V.P. Himija drevesiny i celljulozy. [Wood chemistry and pulp]. Moscow, 1978, 368 p. (in Russ.)

11. Drevesinovedenie. Himicheskij sostav drevesiny. [Wood. The chemical composition of wood]. [Electronic resource]. URL: http://delostroika.ru/org/dreved/him/3990-himicheskiy-sostav-drevesiny.html (in Russ.)

12. Koichiro Kitao. Chemical Constituents of Tropical Woods, (in Japanese) p. 6.

13. Brown A.G., Thomson R.H. 792. J. Chem. Soc., 1965, pp. 4292-4295, doi: 10.1039/JR9650004292.

14. Knop A., Shejb V. Fenol'nye smoly $i$ materialy na ih osnove. [Phenolic resins and materials on their basis]. Moscow, 1983, $280 \mathrm{p}$.

15. Babkin V.A., Ostrouhova L.A., Malkov Ju.A., Ivanova S.Z., Onuchina N.A., Babkin D.V. Himija $v$ interesah ustojchivogo razvitija, 2001, no. 3, pp. 363-367. (in Russ.)

16. Ivanova S.Z., Fedorova T.E., Ostrouhova L.A., Fedorov S.V., Onuchina N.A., Babkin V.A. Himija rastitel'nogo syr'ja, 2001, no. 4, pp. 21-24. (in Russ.)

17. Kuznecov B.N., Kuznecova S.A., Danilov V.G., Taraban'ko V.E. Himija v interesah ustojchivogo razvitija, 2005, no. 4, pp. 531-539. (in Russ.)

18. Sudakova I.G., Kuznecov B.N., Garynceva N.V., Korol'kova I.V. Himija rastitel'nogo syr'ja, 2010, no. 3, pp. 55-60. (in Russ.)

19. Nikitin N. I. Himija drevesiny i celljulozy. [Wood chemistry and pulp]. Moscow - Leningrad, 1982, 711 p. (in Russ.)

20. Karrer W. Konstitution und Vorkommen der organischen Pflanzenstoffe, Basel, Stuttgart, 1958, 1207 p.

21. Zotov P.D. Proizvodstvo stroitel'nyh plit iz kamysha. [Production of building board made of reeds]. Tashkent, 1941, pp. 6-7.

24. Wakisaka H. Development of functional materials with carbon waste product of natural resources - Yoshi - development of activated carbon from bamboo (in Japanese) 2007. Pp. 23-31

22. Uchimura Etsuzo. Bamboo charcoal \& vinegar (in Japanese) 1999. 187 p.

\footnotetext{
* Corresponding author.
} 
